\title{
Laboratory evaluation of different insecticides against Brevicoryne brassicae and its parasitoid, Diaeretiella rapae (Hymenoptera: Braconidae: Aphidiinae)
}

\author{
Muhammad Jaffar Hussain ${ }^{1}$, Muhammad Anjum Aqueel ${ }^{1}$, Abu Bakar \\ Muhammad Raza ${ }^{1}$ and Saqi Kosar Abbas ${ }^{2 *}$ \\ 1. University College of Agriculture, University of Sargodha, 40100, Sargodha-Pakistan \\ 2. College of Agriculture, BZU, Bahadur Sub-Campus, Layyah-Pakistan \\ *Corresponding author's email: drsaqi@bzu.edu.pk \\ Muhammad Jaffar Hussain, Muhammad Anjum Aqueel, Abu Bakar Muhammad Raza and Saqi Kosar Abbas. \\ Laboratory evaluation of different insecticides against Brevicoryne brassicae and its parasitoid, Diaeretiella rapae \\ (Hymenoptera: Braconidae: Aphidiinae). Pure and Applied Biology. Vol. 9, Issue 1, pp256-268. \\ http://dx.doi.org/10.19045/bspab.2020.90030
}

\begin{tabular}{llll}
\hline \hline Received: 18/07/2019 & Revised: 12/09/2019 & Accepted: 24/09/2019 & Online First: 23/10/2019 \\
\hline \hline
\end{tabular}

\section{Abstract}

The toxicity of six insecticides (Advantage ${ }^{\circledR}$, Pyramids $^{\circledR}$, Polo $^{\circledR}$, Imidacloprid ${ }^{\circledR}$, Match $^{\circledR}$ and Mospilon ${ }^{\circledR}$ ) on Brevicoryne brassicae (Hemiptera: Aphididae) and its parasitoid, Diaeretiella rapae (Hymenoptera: Braconidae) were evaluated under constant laboratory conditions $\left(25 \pm 2{ }^{\circ} \mathrm{C}\right.$; with $65-70 \%$ R.H.). All the tested insecticides were lethal against $B$. brassicae with the passage of time at highest concentration. Maximum mortality was observed in $\mathrm{Polo}^{\circledR}$ and minimum in Mospilon ${ }^{\circledR}$ followed by Advantage ${ }^{\circledR}$, Pyramid $^{\circledR}$, Match ${ }^{\circledR}$ and Imidacloprid ${ }^{\circledR}$. All the LC $_{50}$ s were lethal against its parasitoid with maximum mortality at 48 HAT (Hours after treatment) and minimum in all insecticides at 12 hours after treatment. The maximum mortality (100\%) were observed at 48 HAT in Polo ${ }^{\circledR}$ and Advantage ${ }^{\circledR}$ followed by Imidacloprid ${ }^{\circledR}$ and Pyramid ${ }^{\circledR}$ (93.33\%), Match $^{\circledR}(92.33 \%)$ and Mospilon ${ }^{\circledR}(86.67 \%)$. The minimum mortality of D. rapae was recorded at 12 HAT in Mospilon ${ }^{\circledR}$ (36.67\%) as compared to other insecticides. observed harmful (class IV) but only Mospilon ${ }^{\circledR}$ was moderately harmful (class III) to $D$. rapae. Maximum survival ship of $D$. rapae was observed in Pyramid ${ }^{\circledR}$ after 48 HAT and minimum in Polo ${ }^{\circledR}$. In general, D. rapae exhibited the highest sensitivity to all evaluated insecticides. The insecticide Polo ${ }^{\circledR}$ showed maximum and minimum mortality of aphid was observed in Mospilon ${ }^{\circledR}$ application. In case of parasitoid mortality, the maximum mortality was observed at $\mathrm{LC}_{50}$ of $\mathrm{Polo}^{\circledR}$ and minimum at Mospilon ${ }^{\circledR}$ and trend of parasitoid mortality was that, Polo $^{\circledR}>$ Advantage $^{\circledR}>$ Match $^{\circledR}>$ Pyramid $^{\circledR}$ > Imidacloprid $^{\circledR}>$ Mospilon $^{\circledR}$.

Keywords: Brevicoryne brassicae; Diaeretiella rapae; Insecticides; Mortality

\section{Introduction}

Brassica crops are attacked by number of insect pests including cabbage aphid, Brevicoryne brassicae L., (Homoptera:
Aphididae) all over the word [1, 2]. In family Brassicaceae, cabbage aphid has caused substantial losses in many crops which comprise the mustards and crucifers [3-5]. It 
prefers feeding on young leaves and flowers and feeding deep into the heads of brussels shoots and cabbage [6-8]. Use of insecticides to control the insect pests in crops is common all over world. Managing population of cabbage aphid is not an easy practice although synthetic insecticides are speciously accessible for usage. However for the control these insect pests, the use of insecticides is fashioned with several disadvantages such as development of insecticide resistance and hazards to nontarget organisms including human $[9,10]$. Application of synthetic pesticides and botanicals are harmful to natural enemies present in field. Due to use of pesticides, the parasitoid survival range, reproductive rate and suitability of host is reduced. These are great threat to natural enemies as well as for pollinators [11].

For the protection of agricultural and surrounding habitats, evaluation of side effects of insecticides on natural enemies is necessary for pesticide registration [12]. Some selected insecticides have been declared useful to natural enemies. In many studies, insecticides exposures have been assessed against biological control agents like natural enemies [13-16]. Insecticides, acetamiprid moderately harmful to $C$. carnea [17], acetamiprid and abamectin residues showed high toxicity to hatched nymph of $D$. brevis [18]. While Emamectin benzoate was found toxic for the survival of parasitoid, $T$. chilonis [19]. Still it is not clear that which insecticides along with their scope are destructive for other beneficial organism. More considerate of pest natural enemy insecticide collaboration is needed to formulate more effective IPM strategies [16]. In some pest management activities, insecticides that have been used as discriminatory shown unsafe effects on beneficial species [20].

In agriculture crops, parasitoids and predators generally contribute the reduction in pest population. Keeping in view the importance of beneficial insects and the ill effects of pesticides to these bio-control agents the present studies were carried out. The aim of present study was to evaluate the side effects of few insecticides used for pest control in canola fields on canola aphid and its parasitoid. The more basic aims were to obtain more data regarding survival ship of parasitoid on the side effects of selected insecticides against parasitoid and prove to investigate the suitability of these insecticides for use in integrated pest management (IPM) programs.

\section{Materials and methods}

\section{Aphid parasitoid (Diaeretiella rapae)}

Population of parasitoids was maintained at $25 \pm 2{ }^{\circ} \mathrm{C}$ temperature and $65-70 \%$ relative humidity in plastics cages. The culture was fed by $10 \%$ honey solution and aphid population was offered for maintenance of culture. The reared parasitoids were used for the investigations.

\section{Canola Aphid (Brevicoryne brassicae)}

Colonies of B. brassicae were collected from canola fields and screened out for the presence of parasitoid(s). Aphids were transferred to glass cages containing 10 plants at least. The colony was maintained at $24 \pm 2{ }^{\circ} \mathrm{C}$ with photoperiod of $16: 8$ (L: D). Plants were replaced at weekly interval [21].

\section{Insecticides}

Different concentrations of insecticides were used against $B$. brassicae under laboratory conditions to check their efficacy. Detail of insecticides used is given in (Table 1).

\section{Bioassays}

To check the effectiveness of insecticides leaf dip bioassay method was used. Leaves were dipped in each concentration for 10 seconds and were completely dried for 15 minutes at room temperature. A slightly moistened filter paper was also placed in petri dishes to keep the leaf material turgid. Twenty apterous aphids were released in each petri-dish on these leaflets using fine 
camel hair brush. Experiment was repeated three times.

Table 1. Detail of insecticides used in study

\begin{tabular}{|c|c|c|c|c|c|}
\hline Trade Name & $\begin{array}{c}\text { Common } \\
\text { name }\end{array}$ & Dose/acre & $\begin{array}{c}\text { Concentration } \\
\text { used }\end{array}$ & $\begin{array}{l}\text { Group of } \\
\text { pesticides }\end{array}$ & Manufacturer \\
\hline $\begin{array}{c}\text { Advantage }^{\circledR} \\
(20 \mathrm{EC})\end{array}$ & Carbosulfan & $500 \mathrm{ml}$ & $\begin{array}{c}0.4 \mathrm{ml} \\
0.2 \mathrm{ml} \\
0.1 \mathrm{ml} \\
0.5 \mathrm{ml} \\
0.25 \mathrm{ml}\end{array}$ & Carbamate & FMC \\
\hline $\begin{array}{c}\text { Pyramids }^{\circledR} \\
(10 \text { SL })\end{array}$ & Nitenpyram & $200 \mathrm{ml}$ & $\begin{array}{l}0.16 \mathrm{ml} \\
0.08 \mathrm{ml} \\
0.04 \mathrm{ml} \\
0.02 \mathrm{ml} \\
0.01 \mathrm{ml} \\
\end{array}$ & Neonicotinoid & Kanzo Ag \\
\hline $\begin{array}{c}\text { Polo }^{\circledR} \\
(500 \mathrm{SC})\end{array}$ & diafenthiuron & $200 \mathrm{ml}$ & $\begin{array}{l}0.16 \mathrm{ml} \\
0.08 \mathrm{ml} \\
0.04 \mathrm{ml} \\
0.02 \mathrm{ml} \\
0.01 \mathrm{ml}\end{array}$ & Neonicotinoid & $\begin{array}{c}\text { Syngenta, } \\
\text { Pakistan }\end{array}$ \\
\hline $\begin{array}{c}\text { Imidacloprid }^{\circledR} \\
\quad(70 \mathrm{WS})\end{array}$ & Imidacloprid & $80 \mathrm{~g}$ & $\begin{array}{l}0.064 \mathrm{~g} \\
0.032 \mathrm{~g} \\
0.016 \mathrm{~g} \\
0.008 \mathrm{~g} \\
0.004 \mathrm{~g}\end{array}$ & Neonicotinoid & Four Brothers \\
\hline $\begin{array}{c}\text { Match }^{\circledR} \\
(0.50 \text { EC })\end{array}$ & Lufenuron & $200 \mathrm{ml}$ & $\begin{array}{l}0.16 \mathrm{ml} \\
0.08 \mathrm{ml} \\
0.04 \mathrm{ml} \\
0.02 \mathrm{ml} \\
0.01 \mathrm{ml} \\
\end{array}$ & IGRs & $\begin{array}{l}\text { Syngenta, } \\
\text { Pakistan }\end{array}$ \\
\hline $\begin{array}{l}\text { Mospilon }^{\circledR} \\
\quad(20 \text { SP) }\end{array}$ & Acetamiprid & $125 \mathrm{~g}$ & $\begin{array}{c}0.1 \mathrm{~g} \\
0.05 \mathrm{~g} \\
0.025 \mathrm{~g} \\
0.0125 \mathrm{~g} \\
0.00625 \mathrm{~g}\end{array}$ & Neonicotinoid & $\begin{array}{l}\text { Arysta Life } \\
\text { Science }\end{array}$ \\
\hline
\end{tabular}

\section{Data recording}

Data of aphid mortality were recorded at 12, 24 and 48 hours of exposure. Corrected mortality was calculated by using Abbott's formula (Abbott, 1925).

Corrected mortality $=1-\frac{\mathrm{n} \text { in T after treatment }}{\mathrm{n} \text { in Co after treatment }} \times 100$

Whereas, $\mathrm{T}=$ treated and $\mathrm{Co}=$ control

\section{Statistical analysis}

Data for percent corrected mortality were analyzed using three factor factorial design under CRD to check the significance of insecticides. $\mathrm{LC}_{50}$ value for each insecticide was calculated by Probit analysis.

Impact of insecticides on Diaeretiella rapae Newly emerged adult parasitoids were tested against $\mathrm{LC}_{50}$ of each insecticides selected from previous experiment. Detail of $\mathrm{LC}_{50}$ of each insecticide is given in (Table 2). 
Table 2. Insecticides with different $\mathrm{LC}_{50}$

\begin{tabular}{|c|c|}
\hline Insecticides & LC $_{50}$ \\
\hline Advantage $^{\circledR}(20 \mathrm{EC})$ & $1.07 \mathrm{ml}$ \\
\hline Imidacloprid $^{\circledR}(70 \mathrm{WS})$ & $0.037 \mathrm{~g}$ \\
\hline Pyramids $^{\circledR}(10 \mathrm{SL})$ & $0.069 \mathrm{ml}$ \\
\hline Diafenthuron $^{\circledR}(500 \mathrm{SC})$ & $0.033 \mathrm{ml}$ \\
\hline Lufenuron $^{\circledR}(0.50 \mathrm{EC})$ & $0.062 \mathrm{ml}$ \\
\hline Acetamiprid $^{\circledR}(20 \mathrm{SP})$ & $0.08 \mathrm{~g}$ \\
\hline
\end{tabular}

\section{Procedure for bioassay}

To check the effect of above mentioned pesticides on the aphid parasitoid, bioassay were carried out into petri dishes. Untreated filter papers were cut into half of the diameter of the petri dish with the help of a scissor. Half of petri dish left without filter paper to provide insecticide free environment to the parasitoids. Systemic insecticidal dilutions $\left(\mathrm{LC}_{50}\right)$ were sprayed through injector on these filter papers. Five pairs of newly emerged adult parasitoids were released in the petri dishes. Artificial food as cotton soaked with $10 \%$ honey solution was also provided. The $\%$ corrected mortality of aphid parasitoids were calculated after 12, 24 and 48 hours using Abbott's formula;

\section{Corrected mortality $=1-\underline{n}$ in T after treatment $x 100$}

\section{Toxicity class}

According to [22] insecticides were classified according to different toxicity classes. These classes were classified on the basis of International organization for biological control (IOBS) and West palaearctic regional section (WPRS) as under,

$\circ$ Toxicity class I (Harmless) = Mortality (less than $50 \%$ )

○ Toxicity class II (Slightly harmful) = Mortality (50-79 \%)
- Toxicity class III (Moderately harmful $)=$ Mortality (80-89 \%)

- Toxicity class IV $($ Harmful $)=$ Mortality (more than $90 \%$ )

\section{Statistical analysis}

Data for percent corrected mortality were analyzed using three factor factorial design under CRD to check the significance of insecticides. $\mathrm{LC}_{50}$ value for each insecticide was calculated by Probit analysis. All the analysis was performed by using Minitab 16.1 and SPSS 17.0 software.

\section{Results}

Percent mortality of $B$. brassicae at different concentrations of insecticides

Different concentrations of used insecticides showed mortality of B. brassicae as shown in (Fig.1). The results showed that all the concentrations of all insecticides had lethal impact to B. brassicae. Concentration one of all pesticides showed maximum mortality of $B$. brassicae. Maximum mortality was observed in $\mathrm{Polo}^{\circledR}$ and was observed in Mospilon ${ }^{\circledR}$ at first concentration followed by Advantage ${ }^{\circledR}, \quad$ Pyramid $^{\circledR}, \quad$ Match $^{\circledR}$ and Imidacloprid $^{\circledR}$. In all tested insecticides the minimum mortality were observed at fifth concentration. It is evident from the results that all the insecticides showed maximum mortality by increasing the concentration of the insecticides. 


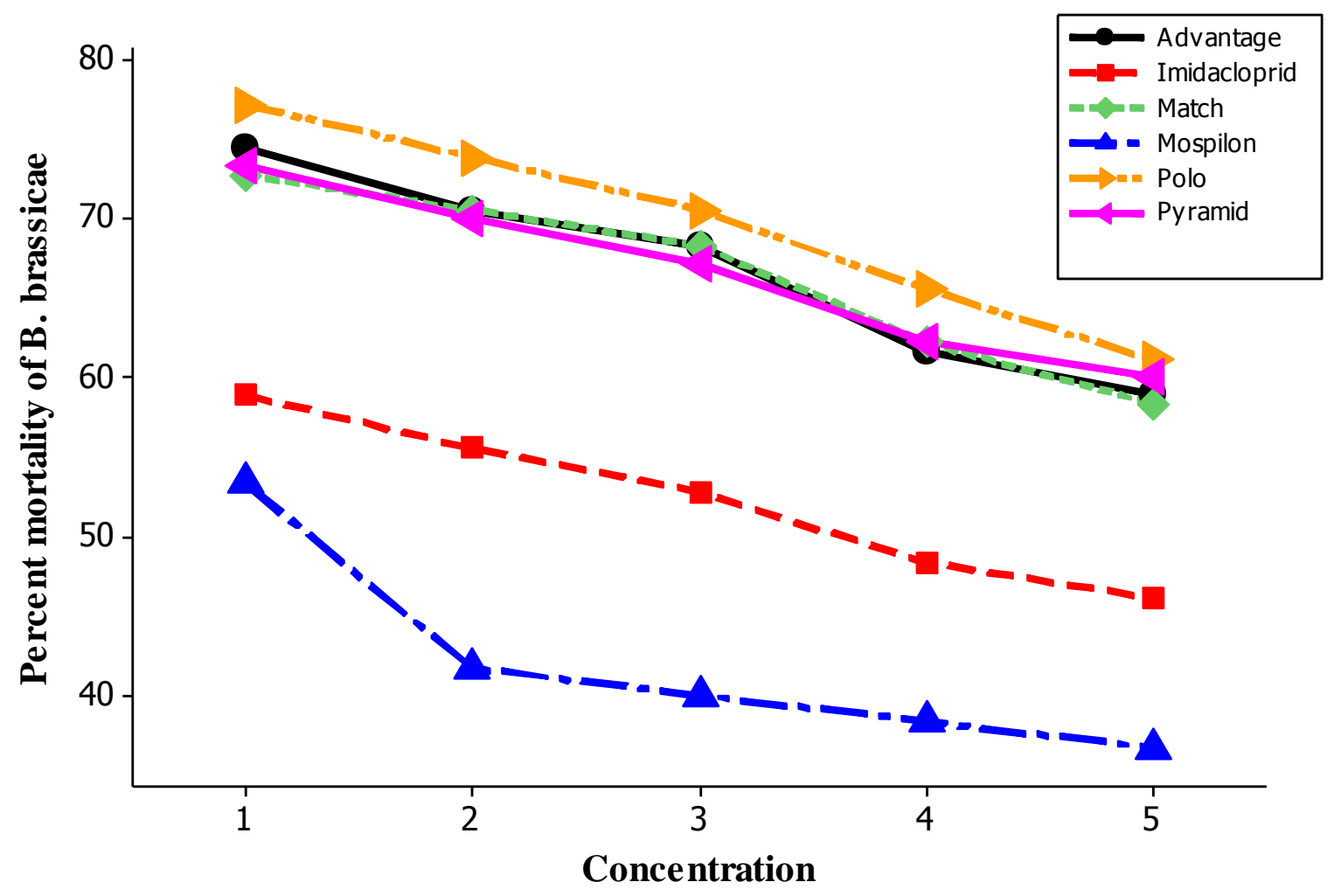

Figure 1. Percent mortality of $\boldsymbol{B}$. brassicae at different concentrations of insecticides

LC $_{50}$ of different insecticides against Brevicoryne brassicae

Lethal concentrations $\left(\mathrm{LC}_{50}\right)$ of different pesticides against $B$. brassicae are shown in (Table 3). These concentrations showed that the toxicological observations under laboratory conditions. The values for Imidacloprid (70 WS), Lufenuron (0.50 EC), Carbosulfan (20 EC), Difenthiuron (500 SC), Nitanpyram (10 SL) and Acetamiprid (20 SP) were $0.037 \mathrm{~g}, 0.062 \mathrm{ml}, 1.07 \mathrm{ml}, 0.033 \mathrm{ml}$, $0.069 \mathrm{ml}$ and $0.08 \mathrm{~g}$ respectively. $\mathrm{LC}_{50}$ values of Carbosulfan (20 EC), Difenthiuron (500 SC), Nitanpyram (10 SL) and Acetamiprid (20 SP) were observed less toxic to $B$. brassicae. The observation of all insecticides varied significantly as the fiducial limits for tested pesticides overlap each tothers. The regression parameters showed that contribution of Imidacloprid (70 WS),
Lufenuron $(0.50 \mathrm{EC})$ to the mortality of $B$. brassicae was highly significant and positive. Impact of insecticides on aphid parasitoid, D. rapae

Effect of different insecticides on the mortality of $D$. rapae at different time intervals

All the insecticides showed maximum mortality at 48 HAT (Hours after treatment) and minimum mortality at 12 hours after treatment. Maximum mortality $(100 \%)$ were observed at 48 HAT in Polo $^{\circledR}$ and Advantage $^{\circledR}$ followed by Imidacloprid ${ }^{\circledR}$ and Pyramid $^{\circledR}$ (93.33\%), Match $^{\circledR}$ (92.33\%) and Mospilon ${ }^{\circledR}(86.67 \%$ ) (Fig. 2).The minimum mortality of $D$. rapae was recorded at 12 HAT in Mospilon ${ }^{\circledR}(36.67 \%)$ as compared to other insecticides. Our findings showed that parasitoids are more sensitive to chemical insecticides than aphids. 
Hussain et al.

Table 3. LC $\mathrm{C}_{50}$ of different insecticides against Brevicoryne brassicae

\begin{tabular}{|c|c|c|c|c|}
\hline Insecticides & $\mathrm{LC}_{50} \pm \mathrm{SE}$ & $95 \% \mathrm{CI}$ & $\chi^{2}$ & Regression \\
\hline 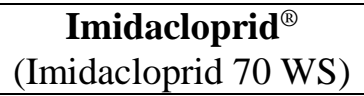 & $0.037 \mathrm{~g} \pm 0.24$ & $0.27-0.45$ & $43.55^{* *}$ & $Y=-0.38+10.25 X$ \\
\hline $\begin{array}{c}\text { Match }^{\circledR} \\
\text { (Lufenuron 0.50 EC) }\end{array}$ & $0.062 \mathrm{ml} \pm 0.08$ & $0.047-0.077$ & $12.39^{*}$ & $Y=-0.35+5.69 X$ \\
\hline $\begin{array}{c}\text { Advantage }^{\circledR} \\
\text { (Carbosulfan 20 EC) }\end{array}$ & $1.07 \mathrm{ml} \pm 1.19$ & $0.54-1.574$ & $8.4^{\mathrm{ns}}$ & $Y=0.04+0.043 X$ \\
\hline $\begin{array}{c}\text { Polo }^{\circledR} \\
\text { (Difenthiuron 500 SC) }\end{array}$ & $0.033 \mathrm{ml} \pm 0.007$ & $0.0177-0.048$ & $9.5^{\mathrm{ns}}$ & $Y=-0.21+6.22 X$ \\
\hline $\begin{array}{c}\text { Pyramid }^{\circledR} \\
\text { (Nitanpyram } 10 \text { SL) }^{\text {(N) }}\end{array}$ & $0.069 \mathrm{ml} \pm 0.011$ & $0.047-0.92$ & $6.78^{\mathrm{ns}}$ & $Y=0.25+3.65 X$ \\
\hline $\begin{array}{c}\text { Mospilon }^{\circledR} \\
\text { (Acetamiprid } 20 \mathrm{SP} \text { ) }\end{array}$ & $0.08 \mathrm{~g} \pm 0.12$ & $0.054-0.11$ & $4.662^{\mathrm{ns}}$ & $Y=-0.41+5.05 X$ \\
\hline
\end{tabular}

* Significant $(\mathrm{P}<0.05),{ }^{* *}$ Highly Significant $(\mathrm{P}<0.001), \mathrm{ns}=$ Non-Significant $(\mathrm{P}>0.05), \mathrm{Y}=$ Percent mortality, $\mathrm{X}=$ Insecticides

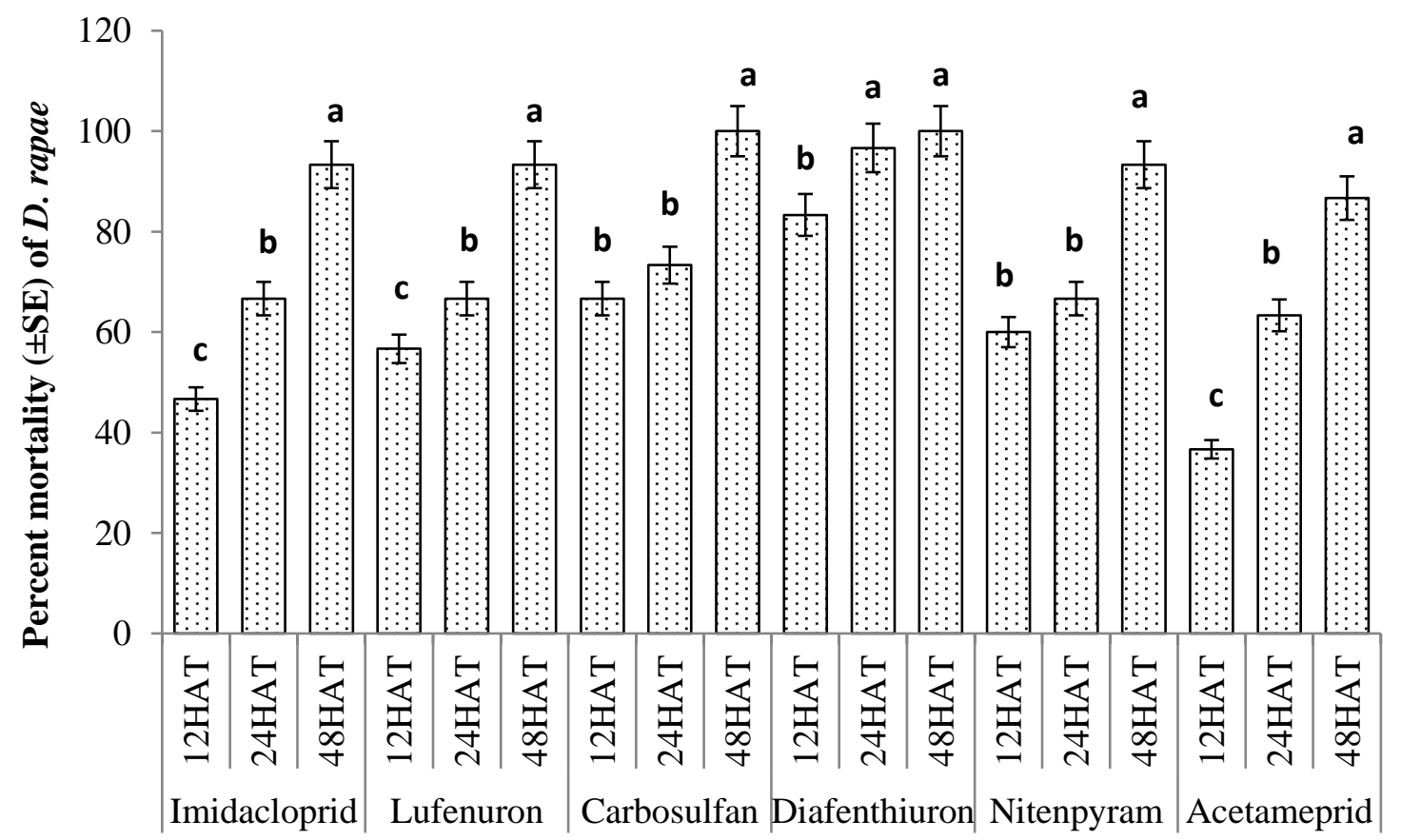

Efficacy of insecticides at different time interval

Figure 2. D. rapae mortality at different time intervals against different $\mathrm{LC}_{50}$ of insecticides (Mean \pm SEM) mean followed by same letters are not significantly different to each other (Tukey's HSD Test, $\mathbf{P} \leq \mathbf{0 . 0 5}$ )

Mortality of $D$. rapae after different exposure and its toxicity class

After the exposure of 12 hours, Imidacloprid (70 WS) and Mospilon ${ }^{\circledR}(20$ SP) were harmless to parasitoid. Advantage ${ }^{\circledR}$ (20 EC), Pyramids $^{\circledR}$ (10 SL), Match ${ }^{\circledR}$ (0.50 EC) were slightly harmful and $\mathrm{Polo}^{\circledR}$ (500 SC) was moderately harmful. After 24 hours, all 
insecticides were slightly harmful to parasitoid except Polo ${ }^{\circledR}$ (500 SC) which was observed harmful. After 48 hours, All the insecticides were observed harmful against parasitoid but only Mospilon ${ }^{\circledR}$ (20 SP) was moderately harmful to $D$. rapae. From present study it can be concluded that all insecticides used against $B$. brassicae were harmful to beneficial insect (Table 4).

Survivorship of $D$. rapae at different time intervals

Survivalship of $D$. rapae at different exposures (12, 24 and 48 hours) is shown in
(Fig. 3). The results showed that 12 hours after treatment, maximum survival of parasitoid $D$. rapae was observed in Mospilon ${ }^{\circledR}$ treatment. After the exposure of 24 hours, maximum survival was observed in Imidacloprid $^{\circledR}$ treatment and minimum in Polo ${ }^{\circledR}$ as compared to other treatments. At 48 hours after treatment, the maximum survival was observed in Pyramid ${ }^{\circledR}$ treated area and minimum same as 24 hours treatment like Polo $^{\circledR}$ as compared to other pesticides treatments.

Table 4. Percentage mortality of $D$. rapae after different exposure and its toxicity

\begin{tabular}{|c|c|c|c|}
\hline Treatments & 12 HAT & 24 HAT & 48 HAT \\
\hline Advantage $^{\circledR}$ (20 EC) (Carbosulfan) & 66.67 (II) & 73.3 (II) & 100 (IV) \\
\hline Imidacloprid (70WS) (Imidacloprid) $^{\circledR}$ & 46.67 (I) & 66.66 (II) & 93.3 (IV) \\
\hline Pyramids $^{\circledR}$ (10 SL) (Nitenpyram) & 60 (II) & 66.6 (II) & 93.3 (IV) \\
\hline Polo $^{\circledR}$ (500 SC) (Diafenthiuron) & 83.3 (III) & 96.67 (IV) & 100 (IV) \\
\hline Match $^{\circledR}$ (0.50 EC) (Lufenuron) & 56.6 (II) & 66.67 (II) & 92.33 (IV) \\
\hline Mospilon $^{\circledR}$ (20 SP) (Acetameprid) & 36.67 (I) & 63.33 (II) & 86.67 (III) \\
\hline
\end{tabular}

Toxicity class I $($ Harmless $)=$ Mortality $($ less than $50 \%)$, Toxicity class II (Slightly harmful) $=$ Mortality $(50-79 \%)$ Toxicity class III $($ Moderately harmful $)=$ Mortality $(80-89 \%)$, Toxicity class IV $($ Harmful $)=$ Mortality $($ more than 90\%), HAT = hours after treatment

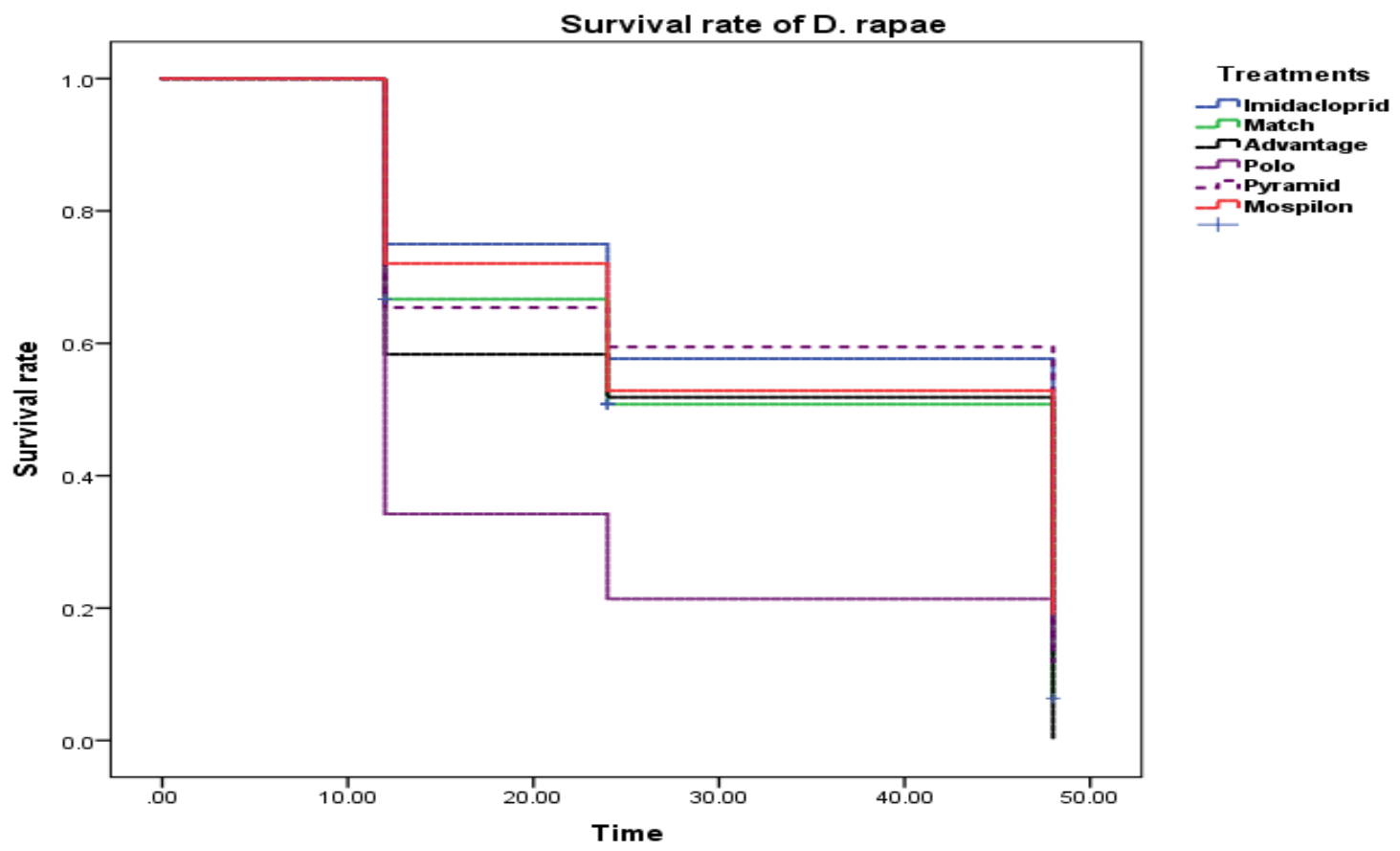

Figure 3. Survivorship of $D$. rapae feeding on B. brassicae at different time intervals 


\section{Discussion}

All the insecticides showed lethal impact against $B$. brassicae at all concentrations. At highest concentration of all insecticides, the $B$. brassicae mortality was maximum. Maximum mortality was observed in Polo ${ }^{\circledR}$ and minimum in Mospilon $^{\circledR}$ at the highest concentration followed by Advantage ${ }^{\circledR}$, Pyramid $^{\circledR}$, Match $^{\circledR}$ and Imidacloprid ${ }^{\circledR}$. Our results are also similar with [23] who investigated nine different insecticides, each have two concentrations against Lipaphis erysimi and found that all the concentrations effective against tested insect. Our findings are also correlates with [24] Razzaq et al. (2010) who observed that imidacloprid and dimethoate caused more than $60 \%$ mortality against $L$. erysimi seven days after application. Our results are similar with [25, 26] who observed that imidacloprid was most effective as compared to endosulfan against L. erysimi with the passage of time interval. According to [27] imidacloprid and dimethoate induced $73 \%$ and $62 \%$ reduction in population of $P$. horticola. Our achievements are also similar with [28] and [29]. They observed same results as present study. In our study all tested insecticides showed maximum mortality after 48 hours and these results are similar with [30] and [31]. Our results are also similar with [32] [33] they observed that all the tested insecticides reduced the aphid population significantly. According to this finding pyramid and imidacloprid showed maximum mortality with the increase in exposure time. In present study, $\mathrm{LC}_{50}$ values of Carbosulfan (20 EC), Difenthiuron (500 SC), Nitanpyram (10 SL) and Acetamiprid (20 SP) were less toxic to host. The observation of all pesticides varied significantly as the fiducial limits for tested pesticides overlap to each other's. The regression parameters showed that contribution of Imidacloprid (70 WS) and Lufenuron (0.50 EC) showed highest mortality. These results are similar to the results of [34] aginst mites [35, 36] aginst aphids and [37] against whiteflies. These all of sucking arthropods who observed that $\mathrm{LC}_{50}$ value of 0.24 micro liter/ml is highly effective for neonicotinoids.

Sadeghi et al. [38] calculated the different other $\mathrm{LC}_{50}$ values for $A$. pisum with the passage of time. Application of imidacloprid decreased the egg laying capacity of $M$. persicae according to [39]. [40] reported that new chemistry insecticides and botanicals are highly effective to reduce the population of $B$. brassicae and recommended for alternative management. Our results emphasized with [41] who used advantage ${ }^{\circledR}$ against mealybug ( $P$. solenopsis) with different concentrations and observed the mortality of mealybug. Our results are also accordance with [42] who observed the toxicity of different insecticides against $L$. erysimi and reported that advantage and imidacloprid showed maximum mortality against $L$. erysimi. In earlier studies, the synthetic insecticides are more successful against aphids ( $S$. avenae and $R$. maidis) for its reduction in population [42-46].

\section{Impact of insecticides on $D$. rapae}

In present study the determined $\mathrm{LC}_{50}$ values were tested against parasitoid to check out the impact against non-target organisms because non selective insecticides decrease the population of natural enemies which results that pest population increased [47]. Due to this incidence of pest population increased, because parasitoids and predators are closely in related with insecticides via its host, direct impact and by consumption of pollen and nectars. The insecticides application may cause the mortality against target as well non target organisms [48]. In many studies, pesticides exposures assessed against biological control agent like natural enemies [13-15, 49].

The results of present study were that all the insecticides showed maximum mortality at 48 HAT (hours after treatment) and 
minimum mortality at 12 hours after treatment. Imidacloprid ${ }^{\circledR}$ was showed $44.67 \%, 66.67 \%$ and $93.33 \%$ mortality after 12, 24 and 48 hours treatment respectively. These results are similar to $[17,48]$ who observed that imidacloprid under laboratory conditions were harmful to $T$. chilonis. Present study found that Match $^{\circledR}$ (Lufenuron) was showed $56.67 \%, 66.67 \%$ and $92.33 \%$ mortality after 12,24 and 24 hours treatment respectively. These findings correlate with the findings of [50] which concluded that lufenuron and imidacloprid showed negative impact on emergence of $T$. chilonis. According to [51] imidacloprid is highly effective against whitefly parasitoid $E$. mundus.

In present findings Mospilon ${ }^{\circledR}$ (Acetameprid) after time interval of 12,24 and 48 hours, treatment showed $36.67 \%, 63.33 \%$ and $86.67 \%$ mortality respectively. These results are similar to [52] who found that different insecticides along with acetamiprid and imidacloprid showed more than $61 \%$ mortality of Encarsia sp. a parasitoid of whitefly. According to findings of [53] that acetamiprid is highly toxic with the passage of time and imidacloprid showed drift toxicity with time intervals due to sunlight effect. Our result are also revealed with the results of [54] who observed that in cotton field of Arizona, the population of predatory arthropods reduced with the application of acetamiprid. According to $[55,56]$ who observed that $A$. colemani is highly sensitive to acetamiprid and indoxacarb and showed maximum mortality.

Present findings resulted that Advantage ${ }^{\circledR}$ (Carbosulfan) showed 66.67\%, $73.33 \%$ and $100 \%$ mortality after 12, 24 and 48 HAT respectively. In treatment where $\mathrm{Polo}^{\circledR}$ (Diafenthiuron) was applied the mortality was $83.33 \%, 96.67 \%$ and $100 \%$ at 12,24 and 48 HAT respectively. These results are similar with the results of [57] who observed that neonicotinoids showed adverse effects to natural enemies. According to [58] who reported that $C$. carnea against carbamate and organophosphate group of insecticides are most sensitive to these pesticides.

The present study resulted that after the exposure of 12 hours the insecticides, Imidacloprid (70 WS) and Mospilon ${ }^{\circledR}$ (20 SP) were harmless to parasitoid. Advantage ${ }^{\circledR}$ (20 EC), Pyramids ${ }^{\circledR}$ (10 SL), Match ${ }^{\circledR}(0.50$ EC) were slightly harmful to parasitoid and Polo $^{\circledR} \quad(500$ SC) after 12 hours was moderately harmful for $D$. rapae. After 24 hours treatment all the applied pesticides were slightly harmful to parasitoid except Polo $^{\circledR}$ (500 SC) which observed harmful for parasitoid. After 48 hours treatment the used pesticides change the toxicity class. All the insecticides were observed harmful to parasitoid, only Mospilon ${ }^{\circledR}$ (20 SP) was moderately harmful to parasitoid. These results are correlated with [59] who observed that acetamiprid revealed great change in toxicity ranging from harmless to harmful against $A$. colemani.

\section{Conclusion}

It was concluded that all insecticides showed maximum mortality with the passage of time. The insecticide Polo ${ }^{\circledR}$ showed maximum and minimum mortality of aphid was observed in Mospilon ${ }^{\circledR}$ application. In case of parasitoid mortality, the maximum mortality was observed at $\mathrm{LC}_{50}$ of Polo $^{\circledR}$ and minimum at Mospilon ${ }^{\circledR}$ and trend of parasitoid mortality was that, Polo ${ }^{\circledR}>$ Advantage $^{\circledR}>$ Match $^{\circledR}>$ Pyramid $^{\circledR}>$ Imidacloprid $^{\circledR}>$ Mospilon $^{\circledR}$. $\mathrm{LC}_{50}$ values of different insecticides showed 70 to $80 \%$ mortality of parasitoid which showed that parasitoids are more sensitive to insecticides. Maximum survival of parasitoid after 12, 24 and 48 hours were observed in Mospilon $^{\circledR}$, Imidacloprid $^{\circledR}$ and Pyramid $^{\circledR}$ respectively. The toxicity exposure of these insecticides decreased when time period increased. This information is useful for the farmers as well as researcher which insecticide is better and cause minimum 
mortality and maximum survival of parasitoid when application of spray is necessary.

\section{Authors' contributions}

Conceived and designed the experiments: MA Aqeel, Performed the experiments: MJ Hussain, Analyzed the data: ABM Raza \& SK Abbas, Contributed materials/ analysis/ tools: MA Aqeel \& ABM Raza, Wrote the paper: MJ Hussain \& SK Abbas.

\section{References}

1. Kessing JLM \& Mau RFL (1991). Cabbage aphid, Brevicoryne brassicae (Linnaeus). Crop Knowledge Master. Department of Entomology, Honolulu, Hawaii.

2. Tesdeke A \& Gashawbeza A (1994). Progress in vegetable management research: 1985-1992. pp 187-193. In: E. Hearth and Lemma, D. (eds.). Proceedings of the Second National Horticultural Workshop, Addis Ababa, Ethiopia, 1-3 December 1992, IAR/FAO.

3. Griffin RP \& Williamson J (2012). Cabbage, Broccoli and other cole crop insect pests HGIC 2203, Home and Garden information center. Clemson cooperative extension, Clemson University.

4. Opfer P \& Mcgrath D (2013). Oregon vegetables, cabbage aphid and green peach aphid. Department of horticulture. Oregon State University, Corvallis.

5. Hines RL \& Hutchison WD (2013). Cabbage aphids on Vegetable IPM resource for the Midwest. University of Minnesota, Minneapolis, MN.

6. Von-Dohlen CD, Rowe CA \& Heie OE (2006). A test of morphological hypotheses for tribal and subtribal relationships of Aphidinae (Insecta: Hemiptera: Aphididae) using DNA sequences. Mol Phylogenet Evol 38: 316-329.
7. Toper-Kaygin A, Çota F \& Gorur G (2008). Contribution to the aphid (Homoptera: Aphididae) species damaging on woody plants in dresser for managing Homopterous sucking pests of Okra (Abelmoschus esculentus (L.) (Moench). J Pest Sci 79: 103-111

8. Natwick ET (2009). Cole crops: cabbage aphid UC Pest Management Guidelines. University of California Agriculture \& Natural Resources.

9. Yue B \& Liu TX (2000). Host selection, development, survival and reproduction of turnip aphid (Homopera: Aphididae) on green and red cabbage varieties. $J$ Econ Ent 93: 1308-14.

10. Maribet LP \& Aurea CR (2008). Insecticidal action of five plants against maize weevil, Sitophilus zeamais motsch. (Coleoptera: Curculionidae). KMITL Sci Tech J 8: 24-34.

11. Ndakidemi B Mtei K \& Ndakidemi PA (2016). Impacts of Synthetic and Botanical Pesticides on Beneficial Insects. Agri Sci 7: 364-372.

12. Anonymous (1996). Commission Directive 96/12/EC of 8 March 1996 amending Council Directive 91/414/EEC concerning the placing of plant protection products on the market. Off. J Eur Communities L65:20-37.

13. Sanon A Garba M Auger J \& Huignard J (2002). Analysis of the insecticidal activity of methyl isothio cyanate on Callosobruchus maculatuc (F.) (Coleoptera: Bruchidae) and its parasitoid Dinarmus basalis (Rondani) (Hymenoptera: Pteromalidae). J Stored Product Res 38: 129-138.

14. Youn YN Seo MJ Shin JG Jang C \& Yu YM (2003). Toxicity of greenhouse pesticides to multicolored Asian lady beetles, Harmonia axyridis (Coleoptera: Coccinellidae). Biol Cont 28: 164-170.

15. Desneux N Rafalimanana $H$ \& Kaiser $L$ (2004). Dose response relationship in 
lethal and behavioural effects of different insecticides on the parasitic wasp Aphidius ervi. Chemosphere 54: 619-627.

16. Preetha $G$ Manoharan $T$ Stanley J \& Kuttalam S (2010). Impact of chlornicotinyl insecticide, imidacloprid on egg, egg-larval and larval parasitoids under laboratory conditions. J Pl Protect Res 50: 535-540.

17. Nasreen A Cheema GM Ashfaq M \& Saleem MA (2004). Survival of Trichogramma chilonis Ishii (Hymenoptera: Trichogrammatidae) after exposure to different insecticides: Laboratory studies. Pak J Zool 36: 7982.

18. Dong-Soon K Brooks DJ \& Riedl H (2006). Lethal and sublethal effects of abamectin, spinosad, methoxyfenozide and acetamiprid on the predaceous plant bug Deraeocoris brevis in the laborator. Bio-Control 51: 465-484.

19. Hussain D Ali A Mushtaq-ul-Hassan M Ali S Saleem M \& Nadeem S (2012). Evaluation of toxicity of some new insecticides against egg parasitoid Trichogramma chilonis (Ishii) (Hymenoptera: Trichogrammitidae). Pak J Zool 44(4): 1123-1127.

20. Hill TA \& Foster RE (2000). Effect of insecticides on the diamondback moth (Lepidoptera: Plutellidae) and its parasitoid Diadegma insulare (Hymenoptera: Ichneumonidae). J Econ Ent 93: 763-768.

21. Jones AME Bridges M Bones AM Cole R \& Rossiter JT (2001). Purification and caharacterization of a non-plant myrosinase from the cabbage aphid Brevicoryne brassicae (L.). Insect Biochem. Mol Biol 31: 1-5.

22. Hassan SA (1989). Testing methodology and the concepts of the IOBC/WPRS Working

group. In. Pesticides and non-target invertebrates. (P.C. Japson, Ed.) Intercept Wimborn Dorset 1-18.

23. Gour IS \& Pareek BL (2003). Field evaluation of insecticides against mustard aphid, Lipaphis erysimi Kalt. under semi-arid region of Rajasthan. Ind J Pl Prot 31: 25-27.

24. Razzaq M Amer M Aslam M \& Shad SA (2010). Effect of conventional and Neonicotinoid insecticides against aphids on canola, Brassica napus L. at Multan and Dera Ghazi Khan. PakJ Zool 42: 377-381.

25. Aslam M \& Ahmad M (2001). Effectiveness of some insecticides against mustard aphid, Lipaphis erysimi (Kalt.) (Aphididae: Homoptera) on three different crops. J Res (Sci) BZU 12(1): 19-25.

26. Aslam M \& Ahmad M (2002). Effectiveness of some insecticides against cabbage aphid, brevicoryne brassicae (Linn.) (Aphididae: Homoptera). J Res (Sci) BZU 13(2): 145150.

27. Ramesh R \& Ukey SP (2007). Bioefficacy ofbotanicals, microbials and newer insecticides in the management of tomato leafminer, Liriomyza trifolii burgess. Int J Agric Sci 3: 154-156.

28. Aslam M \& Munir M (2000). Effectiveness of some insecticides against mustard aphid (Lipaphis erysimi Kalt.) (Homoptera: Aphididae) on three different crops. J Res Sci 13:145-150.

29. Marghub A Aslam M Razaq M \& Shad SA (2010). Effect of conventional and neonicotinoid insecticides against aphids on canola, Brassica napus L. at Multan and Dera Ghazi Khan. Pak J Zool 42(4): 377-381.

30. Khattak SU Muhammad H Khan AU Aslam Z \& Abid F (2002). Pesticidal control of rapeseed aphid, Brevicoryne brassicae (L.). Pak J Zool 34: 225-228. 
31. Sarwar M Ahmad N Siddiqui QH Rajput AA \& Toufiq M (2003). Efficiency of different chemicals on canola strain Rainbow (Brassica napus L.). Asian J Pl Sci 2: 831-833.

32. Kumar S Krishna M Tripathi RA Singh SV \& Mohan K (1996). Comparative efficacy and economics of some insecticides against the mustard aphid, Lipaphis erysimi Kalt. on mustard. Annals Pl Prot Sci 4 (2): 160-164.

33. Bullock RC \& Pelosi RR (1993). Toxicity of imidacloprid to selected arthropods in the citrus greenhouse and grove. In: Proceeding of the Florida State Horticultural Society Florida Vol. 106, pp. 42-47.

34. Conway HE Kring TJ \& Mcnew R 2003. Effect of imidacloprid on wing formation in the cotton aphid (Homoptera: Aphididae). Fla Entomol 86: 474-476.

35. Herbert KS Hoffmann AA \& Powell KS (2008). As saying the potential benefits of thiamethoxam and imidacloprid for phylloxera suppression and improvements to grapevine vigour. Crop Prot 27: 1229-1236.

36. Ateyyat MA Al-Mazraawi M Abu-Rjai T \& Shatnawi MA (2009). Aqueous extracts of some medicinal plants are as toxic as Imidacloprid to the sweet potato whitefly, Bemisia tabaci. J Insect Sci 9: 1-6.

37. Sadeghi A Van Damme EJM \& Smagghe G (2009). Evaluation of the susceptibility of the pea aphid, Acyrthosiphon pisum, to a selection of novel biorational insecticides using an artificial diet. J Insect Sci 9(65): 1-8.

38. Yu Y Shen G Zhu H \& Lu Y (2010). Imidacloprid-induced hormesis on the fecundity and juvenile hormone levels of the green peach aphid Myzus persicae (Sulzer). Pestic. Biochem. Physiol., 98: 238-242.
39. Shiberu T \& Negeri M (2016). Effects of Synthetic Insecticides and Crude Botanicals Extracts on Cabbage aphid, Brevicoryne brassicae (L.) (Hemiptera: Aphididae) on Cabbage. $J$ Fertil Pestic 7: (162) 2471-2728.

40. Nikam ND Patel BH \& Korat DM 2010. Biology of invasive mealy bug, Phenacoccus solenopsis Tinsley (Hemiptera: Pseudococcidae) on cotton. Karnataka Journal of Agricultural Sciences 23(4): 649-651.

41. Khan RR Rasool I Ahmed S Oviedo A Arshad M \& Zia K (2012). Individual and combined efficacy of different insecticides against Lipaphis erysimi (kalt) (Homoptera: Aphididae). Pak Entomol. 34(2): 157160.

42. Misra HP (2002). Field evaluation of some newer insecticides against aphids (Aphis gossypii) and jassids (Amrasca biguttula biguttula) on Okra. Ind J Ento 64: 80-84.

43. Santharam G Kumar K Chandrasekaran S \& Kuttalam S (2003). Bioefficacy and residues of imidacloprid in chilies used against chili Thrips. Madras Agric J 90 (7-9): 395-399.

44. Soliman SSM \& Kazem MGT (2006). Some natural additives to profenofos for improving its efficacy against whitefly and aphid on squash leaves. $J$ Pest Contr Environ Sci 14(2): 333-349.

45. Akbar M.F Yasmin N Naz F \& Haq A (2008). Efficacy of imidacloprid and endosulfan in comparison with biosal (Biopesticide) against Myzus persicae (Sulzer) on mustard crop. Pak J Entomol Karachi 23 (1\&2): 27-30.

46. Joshi NK \& Sharma VK (2009). Efficacy of imidacloprid (Confidor $200 \mathrm{SL}$ ) against aphids infesting wheat crop. $J$ Central Eur Agri 10 (3): 217-222.

47. Gallo D Nakano O Silveira-Neto S Carvalho RPL Baptista GC Berti-Filho E 
Parra JRP Alves SB Vendramin JD Marchini LC Lopes JRS \& Omoto C (2002). Manual de Entomologia Agrícola Piracicaba Fealq 69p.

48. Tomizawa M \& Casida JE (2003). Selective toxicity of neonicotinoids attributable to specificity of insect and mammalian nicotinic receptors. Ann Rev Entomol 8: 339-36.

49. Preetha $G$ Stanley $T$ Suresh $S$ \& Kuttanlam S (2009). Toxicity of selected insecticides to Trichoramma chilonis: Assessing their safety in the rice ecosystem. Phytoparasitica 37: 209215.

50. Hussain D Akram M Iqbal Z Ali A \& Saleem M (2010). Effect of insecticides on Trichogramma chilonis Ishii. (Hymenoptera: Trichogrammatidae) immature and adult survival. J Agric Res 48: 531-537.

51. Sohrabi F Shishehbor P Saber M \& Mosaddegh MS (2013). Lethal and sublethal effects of imidacloprid and buprofezin on the sweet potato whitefly parasitoid Eretmocerus mundus (Hymenoptera: Aphelinidae). Crop Prot 45: 98-103.

52. Bacci, L., A.L.B. Crespo, T.L. Galvan, E.J.G. Pereira, M.C. Picanço, G.A. Silva and M. Chediak, 2007a. Toxicity of insecticides to the sweet potato whitefly (Homoptera: Aleyrodidae) and its natural enemies. Pest Manage Sci 63: 699-706.

53. Tomlin CDS (2009). The pesticide manual, 15th ed. British Crop Production Council, Alton, United Kingdom.
54. Naranjo SE \& Akey DH (2005). Conservation of natural enemies in cotton: comparative selectivity of acetamiprid in the management of Bemisia tabaci. Pest Manage Sci 61: 555-566.

55. Stara J Ourednickova J Kocourek F (2011). Laboratory evaluation of the side effects of insecticides on Aphidius colemani (Hymenoptera: Aphidiidae), Aphidioletes aphidimyza (Diptera: Cecidomyiidae), and Neoseiulus cucumeris (Acari: Phytoseidae). J Pest Sci 84: 25-31.

56. Bostanian NJ Akalach M (2004). The contact toxicity of indoxacarb and five other insecticides to Orius insidiosus (Hemiptera: Anthocoridae) and Aphidius colemani (Hymenoptera: Braconidae), beneficial used in the greenhouse industry. Pest Manage Sci 60: 12311236.

57. Cloyd RA \& Bethke JA (2010). Impact of Neonicotinoid insecticides on natural enemies in greenhouse and interior scape environments. Pest Manage Sci 67: 3-9.

58. Badawy HMA \& EL. Arnaouty SA (1999). Direct and indirect effects of some insecticides on Chrysoperla carnea (Stephens) (Neuroptera: Chrysopidae). J Neuroptol 2: 67-76.

59. Takahashi $\mathrm{Y}$ Kojimoto $\mathrm{T}$ Nagaoka $\mathrm{H}$ Takagi Y \& Oikawa M (2005). Tests for evaluating the side effects of chlorothalonil (TPN) and spinosad on the parasitic wasp (Aphidius colemani). J Pestic Sci 30: 11-16. 